\title{
Study on Dominant American Cultural Values behind Forrest Gump
}

\author{
Qingyuan Li \\ College of Humanity and Social Science, Sichuan Agricultural University, Ya’an 625014, China
}

Keywords: Forrest Gump; American culture; values

\begin{abstract}
In the 1990s of the last century, there was a movie creating a stir as soon as it was released, which not only gained the box office as high as 253 million, but also won the awards including best movie, best director, and best actor etc. in the 67th Oscar. The sensational movie was Forrest Gump, which absolutely had enough elements that could attract audiences, including the success of the retarded protagonist through struggle, famous persons and events in the American history integrated by the movie, reminiscence and sentiment of love and friendship, and humorous and joyful imagination occasionally appearing in the movie. However, the more important essence of the film is that it reflects such dominant American cultural values as individualism, equality, success through diligence, as well as progress and change.
\end{abstract}

\section{Introduction}

Forrest Gump was viewed as an American culture classic of the day when it was released. American magazine Entertainment Weekly compared this movie's influences on American society with that of "Elvis Presley", American movie “The Extra-Terrestrial” and President Lincoln.

The movie Forrest Gump got 13 Oscar nominations in 1995, and eventually gained six Oscar awards. Forrest Gump became an idol in American people's heart overnight. Actually, the hero of this movie was just a mere nobody with a very low IQ of 75, but he had experienced many changes of America after World War II. Those things, such as Vietnam War, the assassination of President John F. Kennedy, Watergate, Ping-Pong diplomacy etc. all left historical imprints on his life. This post-modernism movie showed people "American spirit" through telling the magic story of Forrest Gump, which made the hero figure on the screen write a documentary in the American history for creating a series of life miracles and bringing people a kind of inspiration to life lighted by hope and optimism. This article intends to make a detailed study of dominant American cultural values embodied in Forrest Gump.

\section{The Dominant American Cultural Patterns}

Values are, according to Rokeach, "a learned organization of rules for making choices and for resolving conflicts." ${ }^{[1]}$ Nanda and Warms proposed that "Values are shared ideas about what is true, right and beautiful that underlie cultural patterns and guide society in response to the physical and social environment." [2] Albert also held that "A value system represents what is expected or hoped for, required or forbidden. It is not a report of actual conduct but is the system of criteria by which conduct is judged and sanctions are applied.” [3]

"Although each of us has a set of unique value system, there are also values that tend to permeate a culture. These are called cultural values." ${ }^{44]}$ Cultural values may manifest themselves in behavior patterns or in the end- state of life through the people in the culture. By observing the values of a cultural group, one can appreciate the behaviors of the members in the culture better and make more accurate interpretations and predictions on what they do and say in interpersonal communication.

The manner in which people perceive the world rests on much more than beliefs and values. Cultures are extremely complex and consist of numerous interrelated cultural orientations besides beliefs and values, including attitudes, norms, and material aspects. A useful umbrella term that allows people to talk about these orientations collectively rather than separately is cultural patterns, which refers to both the conditions that contribute to the way in which a person perceive and think 
about the world, and the manner in which they live in that world. "In America, the dominant culture is that part of the population that controls and dominates the major institutions, determines the flow and content of information, and is consequently white, male, and of European heritage." ${ }^{[4]}$ In the society which is full of competitions, everyone's mode and quality of life are decided by his or her own ability, so everyone should struggle for their own life. American people show us the entrepreneurial spirit in their seeking for success. Dominant American cultural patterns, such as individualism, equality, materialism, science and technology and so on guide American people to go forward and try to gain success and happiness.

\section{The Embodiment of Cultural Values in Forrest Gump}

The single most important pattern in the United States is individualism. Broadly speaking, individualism refers to the doctrine, spelled out in detail by the seventeenth-century English philosopher John Locke, that each individual is unique, special, completely different from all other individuals, and "the basic unit of nature."[5]

Everyone in the movie had his or her own personality: sincerity and persistence of Forrest Gump, the toughness and positiveness of his mother, the rebellion and perplexity of Jenny and the grudge and helplessness of Lieutenant Dan. Every person lives in this world with his or her own particular life pattern, challenging the destiny or drifting with the current or willing to destroy.

In this movie, although Forrest had a low IQ of 75, he created his life road with the positive beliefs from his mother. Whichever the life period he was in, he achieved success and fulfilled his value of life through his own efforts. Low IQ didn't become the fetter of Forrest's life; on the contrary, it reflected his great wisdom. He created his life all by himself. Without other people's help, he could also gain more achievements than other normal people. In order to escape from other children's bullying, Jenny asked Forrest to run, so he ran. In the army, he said: "For some reason, I fit in the army like one of them round pegs. It's not really hard. You just make your bed neat, remember to stand up straight and always answer every question with "Yes, drill sergeant." When he firstly finished putting the weapon together, the drill sergeant asked him: "Why did you put that weapon tighter so quickly?" He answered: "You told me to, drill sergeant." ${ }^{[6]}$ He listened to the indications of the drill sergeant, and finished them well. In the hospital, a man taught Forrest to play Ping-Pong. He told Forrest that the secret to the game was no matter what happened, never, ever take his eye off the ball. Forrest just did as he told, and gained surprising success. In the army, Bubba always told Forrest many things about shrimping, and said to Forrest he want to be a captain of the shrimping-boat. So Forrest went on with Bubba's dream when he left the army. From these plots, we can see Forrest just did things as the people told him to. He had no definite purpose, but he could do things better than other people. Maybe this was because he concentrated all his thoughts and energy on one thing, so he got success with firm belief. Many people were burdened by things from outside environment, while Forrest was not. He had simple minds and did simple things, but gained great achievements. Although people thought Forrest was an idiot, he had done things that a talent might not do. Forrest was different from others and he had his own separate identity. He didn't need people's pity and too much help, but he could achieve his goal by his independent strength. His sincerity and persistence were destined to be the cornerstone of his successful life. There was a plot in the movie. Jenny prayed to god: "Dear God, make me a bird so I can fly far, far, far away from here.” ${ }^{[6]}$ Finally she didn't become a free bird. But Forrest did. We can imagine Forrest became a bird flying in the vast sky with his own strong wings.

Closely related to individualism is the American value of equality, which is emphasized in everything from government (everyone has the right to vote) to social relationships ("just call me by my first name"). Americans believe that all people have a right to succeed in life and that the state, through laws and educational opportunities, should ensure that right. For Americans, equality of opportunity may be thought of as an ethical rule. It helps ensure that the race for success is a fair one and that a person does not win just because he or she was born into a wealthy family, or lose because of race or religion.

The motive of Forrest's individual struggle was that he believed although he was a retarded 
person, he could also gain the chance for success if he worked hard like others, which was the belief his mother gave him. Forrest's IQ was only 75, being lower than so called normal people. In other words, he was a little stupid, and his back was as crooked as a politician, so he had to fix braces on his legs. In this situation, Forrest could only go to a special school, not regular school, to study, but his mother wanted him to have the finest education and insisted that he get the same opportunities as everyone else. She thought Forrest enjoyed the same chance to receive regular education and argued it with the principal. She taught him that every soul was equal in front of god, so he had the right to get equality and own all the good things, including love and family. The essential spirit of "equal opportunity" is that people aren't deprived of the chances of equal competition because of their low status in society, politics and economy, and people also shouldn't be discriminated in the competition because of their beliefs, complexion, and accent. Forrest had achieved great success in many fields, which was due to his simple belief of persistence. He had no other specialty, except running. His only talent was only to escape from other children's bullying. When he got rid of the braces on his legs, he seemed to be destined to conquer the world. Forrest used his special way-simplicity, looking at the world as simple as possible to subjugate it. There are some certain formulas in the world. When one can't change them, gloom and resisting all the time may only result in helpless autism. Forrest submitted to all the regulations without considering other choices and made unremitting efforts to do the things he wanted to do and what he should do. The world prefers obedient ones rather than "fortune favors fools". Forrest found the orientation that the world gave him, so he could get success.

Americans believe in the value of hard work. "The North American continent was rich in natural resources when the first settlers arrived, but all these resources were undeveloped. Only by hard work could these natural resources be converted into material possessions, allowing a more comfortable standard of living. Hard work has been both necessary and rewarding for most Americans throughout their history." "7] For most Americans, work is a desired and desirable expenditure of energy, a means of controlling and expressing strong affective states, and an avenue to recognition, money, or power.

Forrest's great success couldn't be parted with his unremitting efforts. When he found he could run like the wind blew in his childhood, from that day on, he was running if he was going somewhere. It was his persistent running that made him join in the football team of the university, save many fellow soldiers in Vietnam War , and run across America for four times. His spirit of persistence and enduring hardships made him known by people and won much fame and honor; when he had learned how to play Ping-Pong in the hospital, he started playing it all the time. He played Ping-Pong even when he didn't have anyone to play with. He was so studious that finally he could play it like a duck in water, so the Army decided he should be on the All-American Ping-Pong team and visit the land of China. When he came back, he became a national celebrity and was received by President Nixon. When Forrest's service was over, he could have chosen a stable and comfortable job, but he chose to shrimp in order to accomplish Bubba's wish. He spent all the money buying a shrimping-boat when he had a sum of money, and became a shrimping-boat captain. Bubba didn't ask him to do so, nor did other people, but Forrest was willing to finish Bubba's dream and support his family just for the true friendship between them. It was doomed that the shrimping life was so hard. The boat floating in the sea, Forrest had to be exposed to the weather, but he bore the hardship without complaint. He had little harvest at the beginning. Then he encountered a tremendous storm that threatened to sink his boat and took away his life. Faced with these difficulties and dangers, Forrest didn't give up but chose to continue. Maybe his persistence touched god, he finally became a billionaire. Later, because Forrest had been a football star and war hero and national celebrity and a shrimping-boat captain and a college graduate, the city of Greenbow decided to get together and offered him a fine job after his mother died. So he could never go back to work for Lieutenant Dan. Although he was a billionaire, he liked doing things so much, so he cut the grass for free. When Forrest had achieved success and acquired fame, people naturally thought he should stop his walk and just enjoy the wonderful life. But he chose to challenge himself all the time. The virtue of diligence was always in his success. 
The experience of Forrest made many "smart people" so pale by comparison. The director just wanted to use the image of Forrest to satirize the people in modern society who forget to work, but corrupt with complaint. Perseverance and consistence ran through Forrest's all experiences. He treated everything like this. Surely he should be successful.

Perhaps more than any other people, Americans place great emphasis on progress and change. From changing themselves with the assistance of self-help gurus, to changing where they live at a faster rate than any other people in the world, they do not value the status quo. The French writer Alexis de Tocqueville, after visiting the United States over a hundred years ago, reached much the same conclusion when he wrote that the people in the United States "All consider society as a body in a state of improvement, and humanity as a changing scene." ${ }^{[4]}$ From the culture's earliest establishment as a distinct national entity, there has been a diffuse constellation of beliefs and attitudes that may be called the cult of progress. These beliefs and attitudes produce a certain mind-set and a wide range of behavior patterns. Various aspects of this orientation are optimism, receptivity to change, emphasis on the future rather than the past or present, faith in an ability to control all phases of life, and confidence in the perceptual ability of the common person. Belief in progress fosters not only the acceptance of change, but also the conviction, true or false, that changes tend in a definite direction and that the direction is good. Each new generation in the United States wants its opportunity to be part of that change.

Progress and Change is an inseparable part of American cultural value, we can notice some plots in Forrest Gump that can reflect it. Forrest's life was not invariant all the time, but colorful and full of challenges and miracles. From Forrest's study period to the latter life, his life was always in change. To a retarded person, his life, in people's thoughts, should be ordinary. His greatest achievement was not more than that he can do a thing well, not making his life too disappointing. So to Forrest, people certainly thought he should go to a special school like other retarded children and learn a kind of skill, then find an ordinary job to pass his time. But with his mother's insistence, he went to a good regular school like normal students. From primary school to secondary school then to university, he finished his education by his "scuds". After his graduation from college, many people may think he should go home this time. But he chose to join the army, then he became a shrimping-boat captain to accomplish his friend's wish, then he became a gardener after having donated his money, and then he became a famous person again for running. It was easy for Forrest to adapt to the changes and face the challenges calmly. Whatever he did, he could achieve success and made progress through his own perseverance and diligence. His life was beyond one's expectations all the time, but always brought people surprise and touching. In the movie, Forrest dodged with tension when Jenny told him that they had a child. Then he asked Jenny: "Is he smart?" "He's very smart. He's one of the smartest in his class", Jenny answered. In the last part of the movie, when little Forrest was going to take the bus, the woman driver whose bus Forrest once took asked him: "You understand this is the bus to school, don't you?" Little Forrest answered: "Of course, and you're Dorothy Harris, and I'm Forrest Gump." ${ }^{[6]}$ From his quick answer, we could know Little Forrest owned sensitive thought and fast reaction, and he was absolutely cleaver. Forrest was retarded, but his son could be smart. Everything was changing. The director gave much thoughts to these plots which could expose life was in change all the time and people were making progress. Progress and Change is a kind of cultural value that American people always believe in and it is also the motive power that promotes human being's history.

\section{Conclusion}

Forrest Gump was reviewed as one of 100 greatest American movies in 1988. It represented thirty-year history of America after World War II in a little man's eyes. America enjoys a high international status in the world, so it influences other countries in every field. American movies as a way to transmit its values and spirits are also of great importance to culture study. Studying American movies can help people have a better understanding of American cultural values, and China can take the essence and discard the dregs to shape its own national culture. Chinese movie industry can also learn from the movie production methods of Hollywood to produce better movies, 
which can communicate fine Chinese traditional culture and attract more audiences at home and abroad. The American cultural values are exerting great influence on Sino-American communication. So a detailed research on American cultural values reflected in the movie is worthy of great efforts.

\section{References}

[1] Rokeach. M. The Nature of Human Values[M]. Newyork, Free Press, 1793, p: 5

[2] Li Mingming. An Inter-Cultural Comparison between Sino -American Cultural Values[MA]. Dongbei University of Finance \& Economics, 2007, p: 6

[3] Albert,E. "Value System," in The International Encyclopedia of the Social Sciences, vol. 16[M]. New York, Macmillan, 1968, p: 32

[4] Samovar, Larry A., and Porter, Richard E., and Stefani, Lisa A. Communication Between Cultures, $3^{\text {rd }}$ ed $[\mathrm{M}]$. Beijing, Foreign Language Teaching and Research Press, 2002, p: 60, p: 62, p: 64

[5] Stewart, E.C., and Bennett, M.J. American Cultural Patterns: A Cross-Cultural Perspective [M]. Yarmouth, Me: Intercultural Press, 1991, p: 133

[6] Forrest Gump, directed by Robert Zemeckis, 1994.

[7] Datesman, Maryanne Kearny, and Crandall, Joann, and Kearny, Edward N. The American Ways: A Introduction to American Culture, 2nd ed[M]. Beijing World Publishing Corporation and Simon\& Schuster Inc., 1999, p: 27 